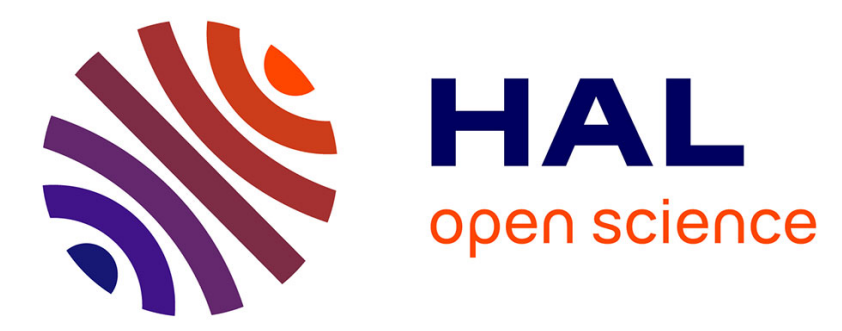

\title{
Book Review: Another World is Possible: Popular Alternatives to Globalization at the World Social Forum \\ Chan Chee Khoon
}

\section{To cite this version:}

Chan Chee Khoon. Book Review: Another World is Possible: Popular Alternatives to Globalization at the World Social Forum. Global Social Policy, 2005, 5 (3), pp.386-389. 10.1177/146801810500500309 . hal-00571775

\section{HAL Id: hal-00571775 \\ https://hal.science/hal-00571775}

Submitted on 1 Mar 2011

HAL is a multi-disciplinary open access archive for the deposit and dissemination of scientific research documents, whether they are published or not. The documents may come from teaching and research institutions in France or abroad, or from public or private research centers.
L'archive ouverte pluridisciplinaire HAL, est destinée au dépôt et à la diffusion de documents scientifiques de niveau recherche, publiés ou non, émanant des établissements d'enseignement et de recherche français ou étrangers, des laboratoires publics ou privés. 
numerous people-centred initiatives from across the developing world, one fails to appreciate the lessons activists in developing countries can learn from community control and collective action based on the experience of Canada.

Some missing gaps which make this an incomplete collection deal with the lack of a critical analysis of the foremost global public health institution, the World Health Organization (WHO), and the collection would have benefited from such an evaluation. Since this book is on global public health, some overall discussion on WTO and TRIPs and how these relate to health policy would also have been useful. Moreover, except in some chapters, there is almost no discussion on multinational pharmaceuticals, NGOs, donors or International Nongovernmental Organisations (INGOs), all increasingly key players in defining any agenda for global public health. Despite some of the weaknesses identified, this is a varied and interesting collection which should interest social scientists, policy makers and practitioners of public health.

S. Akbar Zaidi

Independent Researcher, Pakistan

william fisher and thomas ponniah (eds), Another World is Possible: Popular Alternatives to Globalization at the World Social Forum. London: Zed Books, 2003. 384 pp. ISBN: 1-84277-328-3; US\$19.95 (pbk).

In his brief write-up on the 5th World Social Forum (WSF; Porto Alegre, 26-31 January 2005) Roger Burbach (2005) remarked on the contrasting situations of Presidents Lula (Brazil) and Chavez (Venezuela), the two Heads of State who were in attendance.

Lula, elected President of Brazil in late 2002, inherited a US\$230bn foreign debt along with all the policy dictates, contingencies, and institutional constraints of the presidency of an embedded dependent capitalist formation. These strictures, rather than bad faith, would have curtailed any president's room for manoeuver. More pertinent is the extent to which Lula had exploited even that limited leeway to alter the balance of forces within Brazil, in the face of unrelenting pressure from foreign capital and local elites, to deliver on his promises of agrarian reform and the elimination of hunger and malnutrition.

Chavez on the other hand, reinstated by a popular uprising and loyalist detachments after a US-backed coup by Venezuela's privileged elites in 2002, moved swiftly to capitalize on the momentum of the restoration and to consolidate his populist base. As part of a conscious strategy to entrench the mobilization and vigilance of mass constituencies, more than US\$4bn from Venezuela's oil revenues have been deployed in 'public health and medical programs, educational training for workers, agrarian reform, literacy programs, low income housing, and many other programs' to deliver tangible benefits to Venezuela's impoverished and marginalized communities. 
In their edited selection of conference and workshop syntheses, position papers, analytical insights and campaign experiences, and manifestoes and demands from the 2nd WSF (January 2002, Porto Alegre), William Fisher and Thomas Ponniah highlighted a similar tension between cautious pragmatic reformism, and more radical challenges to the status quo and the powers that sustained it.

This dichotomy was much in evidence too at the 5th WSF, which I attended as part of the People's Health Movement (PHM) delegation to Porto Alegre. But this dichotomy may also be recognized as a complementary two-pronged strategy, which yields incremental (reformist) concessions only when radical challenges become sufficiently plausible and therefore threatening to the status quo.

A century earlier, Rosa Luxemburg had written in 1900 that 'work for reform does not contain its own force, independent from revolution. During every historic period, work for reforms is carried on only in the direction given to it by the impetus of the last revolution, and continues as long as the impulsion from the last revolution continues to make itself felt' (cited in Shaoul, 2003: 157).

We can expect that such themes and debates (reformism vs. radicalism, engagement vs. agitation) will recur in future WSFs, sometimes with acrimony, sometimes with more understanding of their interlinked character.

Some themes from Fisher and Ponniah's selection, however, may have been overtaken by developments since the 2nd WSF. Already at Mumbai (WSF4) and perhaps earlier, where health activists sought to reclaim the radical roots of the Alma Ata primary health care (PHC) vision, concerns had moved beyond the earlier focus on access to essential medicines, undoubtedly an urgent matter of continuing worldwide relevance, to a more comprehensive perspective on the social ecology of health and disease. ${ }^{1}$ This includes of course the social and political determinants of health, and the coping responses of human societies towards illness and infirmity, within a paradigm which seeks to capture the dynamic, interactive complexity, and the interpenetrating unity of the social, natural and created environments which embed the health and disease experience of individuals and populations (Levins and Lewontin, 1985).

The chapter by Oxfam on 'Knowledge, Copyright and Patents', however, gives some insight into the tactical thinking behind the choice of access to essential medicines as a key campaigning issue of global importance.

In a succinct and thoughtful contribution, Oxfam delineates the underlying issues thus:

Will knowledge be monopolized by corporate interests for private profit, and shaped by the markets of rich consumers, or will it be kept within the public domain, and used to help end poverty, hunger and disease? The World Trade Organisation's TRIPs agreement, introduced in 1995 after intense corporate lobbying is at the center of this controversy. It is the main international treaty determining rights over intellectual property (IP), which includes patents, copyrights, and trademarks. 
Moving on to campaign strategies, Oxfam introduces the notion of 'wedge issues':

a key question is whether it is more effective to campaign for broad reform/ abolition of TRIPs, or to focus on achieving change in specific areas, such as patenting of medicines, patenting of plant genetic resources, or patenting of life forms. Oxfam tends to focus its campaigning on 'wedge' issues. A wedge issue provides a concrete illustration of a problem caused by global policies in a form that can be easily understood by the broader public. The idea is that once people understand the grassroots human impact of particular policies, they will be encouraged to campaign for broader policy change. So for example, the problem of patents and access to medicines is a wedge issue for the reform of TRIPs. The fact that no poor country could afford expensive patented HIV/AIDS medicines provided a particularly dramatic illustration of the problem.

As an aside, I might add that as a Malaysian participant in Brazil reflecting on intellectual property issues, I was aware that British colonial Malaya was arguably an early beneficiary of biopiracy (the benefits were quite unevenly distributed of course), when Henry Wickham, an English adventurer smuggled 70,000 rubber seeds (Hevea brasiliensis) from the Manaus region of Brazil in 1876 and delivered them to the Kew Gardens in London where some 3000 seedlings were germinated.

Shipments were dispatched to Sri Lanka (Ceylon) and to Singapore where the director of the Singapore Botanical Gardens, Henry Ridley, succeeded in propagating and disseminating them to the receptive climate and soils of the Malayan peninsula, thereby transforming the economic botany and agricultural landscape of the British colony.

Was this biopiracy (along with the ubiquitous and profitable Malaysian oil palms Elaeis guineensis which were similarly translocated from West Africa to Sumatra and Malaya in the early 1900s), or was this more in the tradition of geographical flows and exchanges of genetic resources and planting materials ever since the invention of agriculture 11,000 years ago?

Some four or five years ago, Rural Advancement Foundation International (RAFI; now the Action Group on Erosion, Technology and Concentration [ETC]) together with their non-governmental organization (NGO) allies had considered launching an international campaign for the formal declaration of a Global Genetic Commons. Shortly after, Sir John Sulston, the 2002 Nobel laureate in medicine or physiology who led the UK's human genome sequencing effort, promoted a very similar idea, that the human genome should be declared as the common heritage of humanity, and that information on genomic (nucleotide) sequences should be declared off limits to patents and intellectual property claims. Let's be provocative, and consider if you will that genomics, proteonomics, and transcriptonomics might be thought of as the 'mining' of genetic (and physiologically useful) information from the human genome. Gene hunters, in search of commercially valuable alleles from 
inbred, indigenous populations might be analogous to a technologically sophisticated mining enterprise, declaring in effect: 'We have a sophisticated technology which can mine this exotic mineral found within your national borders. Insofar as you cannot extract it yourself, you deserve no part of the benefits from our successful exploitation of this mineral, which should be considered a "commons resource" in the "global public domain".'

Not surprisingly, these have been contentious issues even within international civil society, and I gathered from Jim Thomas and Silvia Ribeiro, ETC activists at WSF5, that the genetic commons campaign has been shelved indefinitely.

NOTE

1. See for an overview and discussion of theoretical currents in social epidemiology Krieger (2001) and Levins (1996).

REFERENCES

Burbach, R. (2005) 'Chavez and Lula World Social Forum: The Tale of Two Presidents', Counterpunch (5-6 February), accessed on 6 February 2005, http://www.counterpunch.org/burbach02052005.html

Krieger, N. (2001) 'Theories for Social Epidemiology in the 21st Century: An Ecosocial Perspective', International fournal of Epidemiology 30(4): 668-77.

Levins, R. (1996) 'When Science Fails Us', Edinburgh Medal Lecture, accessed 1 December 2003, copy on file, http://www-trees.slu.se/newsl/32/32levin.htm

Levins, R. and Lewontin, R.C. (1985) The Dialectical Biologist. Cambridge, MA: Harvard University Press.

Shaoul, J. (2003) 'Global Capital and Healthcare Reforms: The Experience of the UK', in K. Sen (ed.) Restructuring Health Services (pp. 146-59). London: Zed Books.

Chan Chee Khoon

Universiti Sains Malaysia 